\title{
ANALISIS KESALAHAN SISWA DALAM MENYELESAIKAN SOAL STATISTIKA MTs KELAS VIII
}

\author{
Bila Aprilia ${ }^{1}$ \\ ${ }^{I}$ (Program Studi Pendidikan Matematika, IKIP Siliwangi, Cimahi). \\ * Corresponding Author. E-mail: ${ }^{1}$ bilaaprilia7@gmail.com
}

\begin{tabular}{|l|l|l|}
\hline Receive: 15/01/2020 & Accepted:02/02/2020 & Published: 02/03/2020 \\
\hline
\end{tabular}

\begin{abstract}
Abstrak
Penelitian ini bertujuan untuk menganalisis kesalahan siswa dalam menyelesaikan soal statistika kelas VIII, menggunakan penelitian deskriptif kualitatif dengan metode pengumpulan suatu data, dan menggunakan uji soal sedangkan validitas data dengan cara uji validitas soal. Subjek ini berjumlah 21 orang. Penelitian ini dilaksanakan kepada siswa kelas VIII Madrasah Tsanawiyah At-Taqwa Kabupaten Bandung Barat tahun akademik 2019/2020. Hasil penelitian ini mengungkapkan bahwa kesalahan yang dialami pada siswa bervariasi diantaranya: 1) menyajikan laporan statistik berupa diagram, baik diagram batang atau lingkaran; 2) menentukan nilai rerata dari sebuah soal cerita dan diagram; 3) menentukan keuntungan (\%) dengan mencari rata-ratanya. Sedangkan faktor kesalahan yang bisa mempengaruhi siswa dalam menyelesaikan masalah materi statistika yaitu: kurangnya pemahaman awal materi tentang statistik, motivasi siswa dalam mengikuti proses pengajaran dan pembelajaran, pembelajaran dengan model yang dilakukan kurang memotivasi siswa untuk belajar kreatif dan aktif dalam memahami pelajaran materi statitika.
\end{abstract}

Kata Kunci:Analisis kesalahan, statistika

\begin{abstract}
English-Indonesia)
This study aims to analyze students' mistakes in completing statistical questions for class VIII, using qualitative descriptive research with the method of collecting data, and using test questions while the validity of the data by means of the test validity. This subject is 21 people. This research was conducted to students of class VIII Madrasah Tsanawiyah At-Taqwa West Bandung Regency academic year 2019/2020. The results of this study revealed that errors experienced by students varied including: 1) presenting statistical reports in the form of diagrams, either bar or circle diagrams; 2) determine the average value of a story and diagram problem; 3) determine the profit (\%) by finding the average. While the error factors that can affect students in solving statistical material problems are: lack of initial understanding of the material about statistics, student motivation in following the teaching and learning process, learning with the model that is done is less motivating students to learn creatively and actively in understanding statistics subject matter.
\end{abstract}

Keywords: Error Analysis, statistics. 


\section{Pendahuluan}

Pendidikan sangat dibutuhkan guru ataupun siswa, untuk menambah ilmu dan pengetahuan. Sehingga pendidik diharuskan lebih inovatif dan kreatif dalam pembelajaran di kelas, supaya siswa merasa lebih senang dan bersemangat dalam pembelajaran terutama matematika (Indahsari \& Fitrianna, 2019). Hal tersebut serupa dengan bahwa pengajaranmatematika dilakukan guru supaya pembelajaran tersebut menerapkan inovatif yangbisa mengeksplor wawasan dan memahami suatu materi matematika dan memberikan kesempatan untuk siswa membangun pemahamannyasendiri (Rohaeti \& Hendriana, 2016)

Matematika sebagai pelajaran yang penting, karena selain dituntutkemampuan berpikir seseorang, banyak permasalahan dalam kehidupan yang bisadisajikan ke dalam model matematika (Zanthy, 2016), namun siswa masih memandangpelajaran matematikaitu sangat rumit dan membosankan. Matematikadianggap pelajaran sulit oleh sebagian murid untuk dipahami karena selalu dikaitkandengan rumus dan angka(M, Rukli, \& Baharullah, 2019).Bagi beberapa siswa SMP/MTs pelajaran matematika itu kerap menjadi hal menakutkan sehingga, minat dan semangat dalam belajar menurun baik di rumah atau sekolah. Realita tersebut dipicu denganpenurunan mutu lulusan,terlihatdari kemampuan belajar matematikarendah dibandingkan mata pelajaran yang lain (Agustiva, Ndia, \& Ikman, 2016).

Matematika merupakan sarana untuk memecahkan persoalandalam kehidupan masyarakat. Hal tersebut sependapat bahwa matematikaberguna dalam mengembangkan kemampuan mengukur, menemukan, menggunakan rumus dan menghitungyang dapat membantu konsep pemahaman murid dalamaktivitas sehari-hari(M, Rukli, \& Baharullah, 2019).

Matematika diperlukan oleh semua orang baik dalam kehidupan maupun dalam perkembangan pengetahuan dan teknologi, sehingga perlu dibekalkan sejak dini.
Pembelajaran matematika akanmembekali siswa pengetahuan dan keterampilan dalam menyelesaikan suatu masalahyang dihadapi siswa. Matematika pula hendak menjadikan siswa mempunyai kemampuanuntuk berfikir sistematis, kritis, logis, efektif dan efisien dalam pemecah masalahmatematika. Statistika salah satu pelajaran matematika yang perlu dipelajari. Umumnya, statistika juga disebut bagai ilmu khusus yang mempelajari tentangdata-data, mengembangkan teknik pada pengolahan angka, dan upaya dalammenjabarkannya (Inayah, 2016). Statistika secara khusus diperlukan untuk menguraikan dan memperkirakan gejalayang akan terjadi menurut kumpulan data hasil dari penelitian sehingga kemampuan statistik dibutuhkan untuk menafsirkan, memahaminya, dan mendapat kesimpulan dari suatu data (Yusuf, R, \& W, 2017). Statistika itu cara darisebagian matematika, yang terjalin dengan jalan pengumpulan data, analisis data pengorganisasian, dan interpretasi data numeric(Takaria, 2015). Kemampuan konsep statistik menuntut siswa bahwa harus mempunyai keahlian matematis yangbagus. Berdasarkan Permendikbud No. 24 Tahun 2016.kemampuan yang terkait pada kompetensi dasar bidang statistika yaitu: a)rata-rata nilai, menganalisis sebuah data, modus, median dan sebaran data supaya bisa memprediksi, membuat keputusan dan mendapat menarik kesimpulan, b) menyampaikan, memutuskan masalah yang berkenaan dengan modus, median, nilai rerata, data distribusi, dan data sebaran untuk mengambil simpulan, membuat keputusan, dan membuat prediksi.

Dalam kehidupan sehari-hari, seringkali kita menjumpai informasi mengenai statistika yang disajikan di media. Informasi tersebut tersedia dengan bentuk tabel, angka, maupun grafik. Contohnya Informasi presentase pertumbuhan ekonomi, hasil pooling pemilihan umum, total penduduk. Pemahaman terhadap statistika menjadi berarti dalam kehidupan masyarakat untuk memecahkan suatu persoalan yang terbentuk di kehidupan masyarakat. Dalam 
menyelesaikan masalah, statistika berfungsi menjadi alat dukung untuk mengatasi data kuantitatif yang didapat dari penelitian yang dilaksanakan seseorang. Sehingga, dari menganalisis data statistik akan diperoleh gambaran kondisi, situasi atau fakta dan hasil yang rasional.

Pemahaman akan membantu siswa mengembangkan cara berpikir dan membuat keputusan (Sariningsih, 2014), tetapi dalam memahami ide statistik siswa kurang sempurna. Hal itu dilihat ketika siswa memecahkan masalah statistik yang tidak lengkap jawabannya. Kurangnya kemahiran siswa mengungkapkan ide statistik secara tertulis, lisan, grafik, tabel dan diagram.

Penalaran statistik yaitu jalan seseorang memahami informasi, dan bekerja dengan memakai ide-ide statistik (Garfield, Le, Zieffler, \& Ben-Zvi, 2014). Kelemahan siswa dalam mengutarakan data atau pendapat statistik bisa dilihat dari hasil simulasi formatif yang masih kecil (Maryati \& Priatna, 2017). Minat siswa juga terhadap statistika sangat kurang. Sama dengan ungkapanyang menunjukkan bahwa siswa merasa takut ketika belajar materi statistika dan kurangnya minat siswa terhadap materi statistika (Tishkovskaya \& Lancaster, 2012). Padahal masyarakat juga perlu mempelajari statistika itu sebab banyak di kehidupan yang menampilkan atau memberikan informasi melalui data statitik, sehingga pentingnya penguatan pemahaman statistik di semua bidang kehidupan.

Minat untuk menambah kemampuan masyarakat dalam mengerti sebuah informasi mengenai data statistik tidak harus terbatas pada mereka yang mengajar pelajarannya saja atau yang tertarik dalam mereformasi pendidikan statistik, tetapi semua orang memiliki tanggung jawabnya untuk paham terhadap statistik termasuk siswa sendiri (Hafiyusholeh, 2015).

Berdasarkan informasi dan pengalaman dari guru matematika yang mengajar di SMA Negeri 8 Tanjung Jabung Timur, keberhasilan saat siswa mengerjakan soal matematika masih tergolong rendah, masih banyak siswa yang belum bisa menjangkau ketuntasan belajar,ketidaktuntasan belajar tersebut dikarenakan siswa melakukan banyak kesalahan dan memberikan jawaban yang bervariasi pada saat menjawab soal. Kesalahan yang terus dilakukan siswa salah satunya kesalahan dalam soal perhitungan.

Hal ini dapat disebabkan dalam menyelesaikan soal siswa kurang teliti ataupun terburu-buru dalam mengerjakannya. Ada pula dikarenakan oleh metode mengajar guru ataupun kemahiran guru dalam menyampaikan suatu materi.Teknik mengajar dan pengusaan materi dari guru sangatlah berguna pada proses belajar, dikarenakan apabila metode dalam mengajar tidak tepat dan keterampilan pokok bahasan kurang dari guru, sehingga akan berpengaruh pada kelancaran siswa untuk memahami materi, siswa juga akan melakukan kesalahan saat menuntaskan soal matematika (Aulia, Yarmayani, \& Fitriani, 2017). Sedangkan guru dikaruniai dua kemampuan, yaitu menyampaikan ilmu dan mentransfer ilmu. Proses penyampaian dan transferisasi ilmu tidak akan sukses dengan baik jika tidak ada metode atau gaya mengajar yang terarah, jelas, sisematis, dan memiliki tujuan. Maka, penerapan metode atau kemampuan dalam mengajar sangat diperlukan agar proses penyampaian dan transferisasi ilmu dapat berjalan sesuai yang diharapkan(Djafar, 2018).

Kesalahan pada siswa harus dianalisis untuk mengetahui jenis kesalahan dan faktor yang menyebabkan timbulnya kesalahan yang dibuat siswa dalam mengerjakan soal matematika denganpokok pembahasan statistika. Setelah mengetahui jenis kesalahan serta faktor dari kesalahan yang siswa lakukan maka dapat ditemukan pemecahannya.Dengan demikian, kekeliruan yang sama dapat diminimalisir, akhirnya kinerja belajar matematik bisa ditingkatkan.

\section{Metode}

Metode Uji tes instrumen soal dilaksanakan pada hari Senin pada tanggal 25 Novenber 2019 di Mts At-Taqwa Cihampelas 
Bandung Barat, Jawa Barat. Penelitian ini memakai penelitian bentuk deskriptif dengan menggunakan data kualitatif.Dan hal yang dideskriptifkan itu tentang kesalahankesalahan yang dikerjakan siswa disaat membereskan soal matematika khususnya materi statistika. Instrumen penelitian berbentuk instrumen tes uraian dengan jumlah 5 soal uraian yang dibagikan untuk siswa bersifat heterogen. Data utama penelitian ini yaitu dalam hasil kerja siswa kelas VIII MTs At-Taqwa. Dan Jumlah siswa adalah 21 orang dan diambil 10 sampel untuk dianalisis.

Berdasarkan data tersebut akan diungkapkan, dianalisa, dan dideskripsikan/dinarasikan dengan kata-kata tentang kesalahan pada siswasaat belajar materi statistika. Teknik yang digunakan penelitian ialah mereduksi, menyajikan dan memberikan kesimpulan suatu data yang sudah diperoleh dari peneliti. Dalam penyusunan instrumen, soal tes ini telah divalidasi oleh Mahasiswa IKIP Siliwangi dengan hasil validasi bahwa instrumen yang dipakai valid. Statistik suatu bagian matematika yang saat ini dibutuhkan oleh banyak peneliti selaku alat bantu untuk membuat keputusan apakah penelitian tersebut dapat dipertanggung jawabkan kebenarannya atau tidak. Dari data yang telah diperoleh tersebut akan dihitung menggunakan rumus menurut (Amin, 2016).

$$
\%=\frac{n}{N} \times 100 \%
$$

Rumus tersebut digunakan untuk dianalisisbagian kesalahan dari siswa dalam membereskan soal statistika sebagai berikut:

$$
\%=\frac{\text { Jumlah skor yang diperoleh }}{\text { Skor maksimal }} \times 100 \%
$$

Jadi untuk menghasilkan suatu kesimpulan, haruslah menghitung telebih dahulu data tersebut yang diperoleh kemudian bisa diambil kesimpulan dengan mengetahui suatu fakta yang didapat.Jadi data statistik perlu dihitung untuk mengetahui kebenaran dari suatu data tersebut sehingga mendapat suatu kesimpulan (Bernard, 2015).

\section{Hasil dan Pembahasan}

Berikut ini adalah hasil kesalahankesalahan siswa di kelas VIII berdasarkan indikator yang sudah di persentasekan tiap soalnya.

Tabel 1. Persentase kesalahan jawaban siswa

\begin{tabular}{llc}
\hline No. & \multicolumn{1}{c}{ Indikator } & \multicolumn{1}{c}{$\begin{array}{c}\text { Salah } \\
(\mathbf{\%})\end{array}$} \\
\hline 1. & $\begin{array}{l}\text { Menjelaskan perbedaan data } \\
\text { diskrit dan data kontinu }\end{array}$ & $19,05 \%$ \\
2. $\begin{array}{l}\text { Menyajikan data dalam } \\
\text { bentuk diagram batang }\end{array}$ & $28,57 \%$ \\
3. $\begin{array}{l}\text { Menentukan rata-rata dari } \\
\text { bentuk diagram }\end{array}$ & $42,86 \%$ \\
4. $\begin{array}{l}\text { Menafsirkan data dari } \\
\text { diagram lingkaran serta } \\
\text { menghitungnya }\end{array}$ & $52,38 \%$ \\
5. $\begin{array}{l}\text { Menyelesaikan rata-rata data } \\
\text { dari bentuk tabel }\end{array}$ & $80,95 \%$ \\
\hline & Pada Tabel diatas menunjukkan
\end{tabular}
bahwa kemampuan menyelesaikan soal statistika pada indikator pertama soal ke-1 yang memberikan jawaban kurang tepat ada $19,05 \%$, pada indikator yang kedua soal ke-2 ada $28,57 \%$ yang menjawab tidak benar, pada indikator yang ketiga soal ke-3 ada $42,86 \%$ yang menjawab salah, Indikator yang keempat soal ke-4 yang $52,38 \%$. Dan terakhir indikator yang kelima soal ke-5 bahwa $80,95 \%$ yang menjawab dengan salah. Banyaknya jawaban yang salah yang diberikan siswa, maka penyebab kesalahan dalam menjawab soal statistika adalah sebagai berikut:

Soal no 1

Perhatikan pernyataan berikut ini:

a. Jumlah kendaraan roda empat di Kabupaten Karawang

b. Hasil panen padi di Kabupaten Bekasi dalam ton/tahun

c. Berat rata-rata sapi di suatu peternakan d. Jumlah penduduk di suatu desa pada tahun 2014 
Dari pernyataan di atas, manakah yang termasuk data diskrit dan manakah yang termasuk kontinu? Jelaskan!

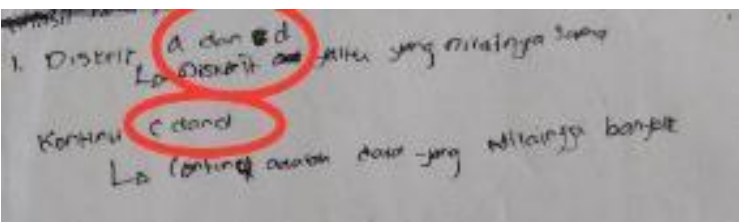

Gambar 1 Jawaban siswa A soal1

Siswa belum memahami apa itu perbedaan kedua data tersebut bisa dilihat dari penjelasan siswa bahwa diskrit itu data yang nilainya sama seharusnya nilainya bilangan asli. Dan dari penjelasan siswa bahwa kontinu adalah data yang nilainya banyak seharusnya yang diperoleh dari hasil pengukuran, besarannya menempatisemua nilai yang berada diantara dua titik. Maka dari itu siswa menjawab soal kurang tepat, dan ketelitiannya kurang karena jawabannya $\mathrm{d}$ ada di keduanya.

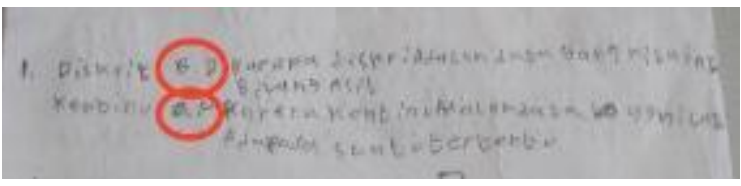

Gambar 2 Jawaban siswa B soal 1

Siswa sudah mengetahui perbedaan data itu sendiri, tetapi siswa masih keliru dalam menentukan termasuk kedalam data mana, meskipun sudah tahu perbedaannya,sehingga siswa hanya menjawab berdasarkan dengan yang di ingatnya saja atau asal menjawab saja tanpa memahami definisi dari kedua data itu.

Soal no 2

Keuntungan Toko "Anggo" perbulan (jutaan rupiah)

\begin{tabular}{|c|c|}
\hline Bulan ke & Keuntungan \\
\hline 1 & 2,5 \\
\hline 2 & 1,8 \\
\hline 3 & 2,6 \\
\hline 4 & 4,2 \\
\hline 5 & 3,5 \\
\hline 6 & 3,3 \\
\hline 7 & 4,0 \\
\hline 8 & 5,0 \\
\hline 9 & 2,0 \\
\hline
\end{tabular}

\begin{tabular}{|l|l|}
\hline 10 & 4,2 \\
\hline 11 & 6,2 \\
\hline 12 & 6,2 \\
\hline
\end{tabular}

a. Buatlah diagram batang dari data tersebut!

b. Sebutkan keuntungan terbesarnya diperoleh Toko "Anggo" selama 1 tahun?

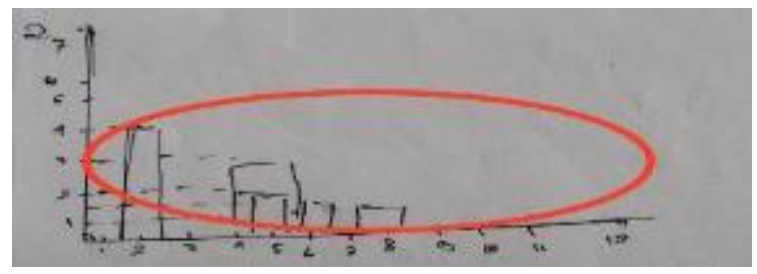

Gambar 3Jawaban siswa A soal 2

Mengetahui sepanjang mana siswa bisa menggambar diagram batang, tetapi berdasarkan jawaban tersebut bahwa siswa kesulitan menggambar diagram batang vertikal, sehingga sebagian siswa mensketsa diagram vertikal pada bulan ke-2 yang seharusnya keuntungan 1,8 tetapi siswa menggambarnya pada keuntungan 4, pada bulan ke-4 seharusnya keuntungan 2,6 tetapi siswa malah menggambarnya pada bulan 4 dan bulan ke-5 diagram batangnya kurang jelas. sama halnya juga pada buan ke-7 dan ke-8 tidak jelas kemana jawabannya itu, siswa tidak menyelesaikan semua soal hanya sebagiannya saja, dan tidak menentukan keuntungan terbesar yang diperolehnya.

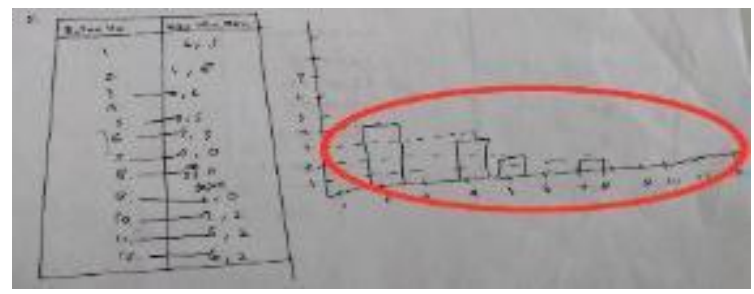

Gambar 4 Jawaban siswa B soal 2

Siswa kesulitan menggambar diagram batang vertical, karena bisa dilihat dari jawaban gambar yang ditulis oleh siswa tidak jelas, sebagian siswa menggambar diagram vertikal pada bulan ke-2 yang seharusnya keuntungan 1,8 tetapi siswa menggambarnya pada keuntungan 4, pada bulan ke-5 seharusnya keuntungan 3,5 tetapi siswa malah menggambarnya pada keuntungan 1,5 begitupun seterusnya. Siswa tidak menyelesaikan semua gambar dengan 
lengkap, dan tidak menentukan keuntungan paling besar selama setahun tersebut.

Soal no 3

"Pengunjung Perpustakaan"

Dijalan Ani menemukan koran yang telah sobek dan disana terdapat data pengunjung perpustakaan berbentuk gambar diagram sebagai berikut:

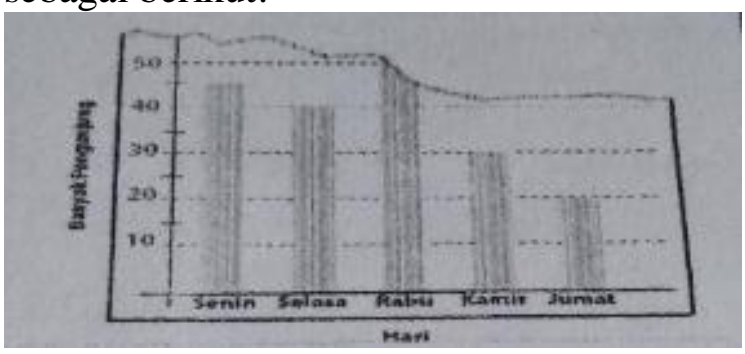

Pengunjung tersebut sebanyak 41 orang selama lima hari rata-ratanya. Disana tidak diketahui berapa orang pengunjung pada hari rabu, maka tentukan berapa banyak orang pengunjung pada hari rabu?

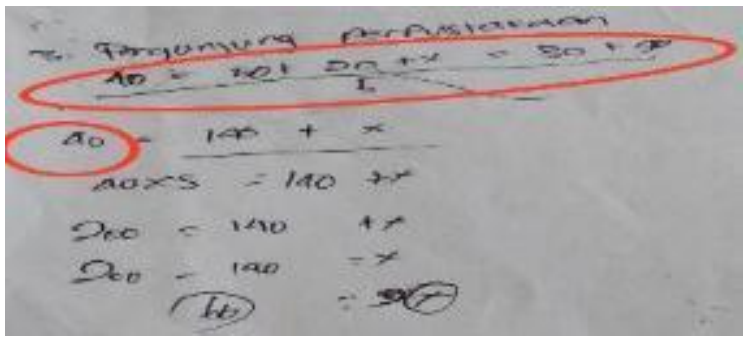

Gambar 5Jawaban siswa A soal 3

Bertujuan mengetahui pengunjung hari rabu, dari jawaban siswa yang diberikan, siswa sulit untuk membuat strategi model matematika selama menyelesaikan soal tersebut sehingga penyelesaiannya tidak lengkap dan keliru, Seharusnya bukan 40 orang rata-rata pengungjung selama 5 hari itu, yang benar itu 41 orang. Dan jumlah yang datang pada hari senin 45 orang, selasa 40, rabu yang ditanyakannya jadi dimisakan $\mathrm{x}$ atau y boleh, kamis 30, jum'at 20 orang. Sehingga ketika di jumlahkan aka mendapat hasil 135+x, bukan 140+x. Dilihat dari jawaban tersebut siswa kurang memahami dalam membaca data dari diagram batang itu sendiri.

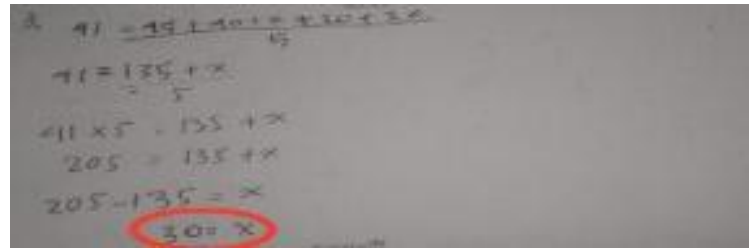

Gambar 6 Jawaban siswa B soal 3

Siswa bagus dalam pehaman konsep soal tersebut, sehingga siswa memberikanjawaban soal dengan tepat, tetapi kurang telitinya siswa ataupun terburu-buru dalam menghitung nilai akhir yang telah siswa dapat, bisa dilihat dari jawaban siswa bahwa 205-135 adalah 30 seharusnya jawaban yang benat itu 70 .

Soal no 4

Perhatikan gambar diagram dibawah!

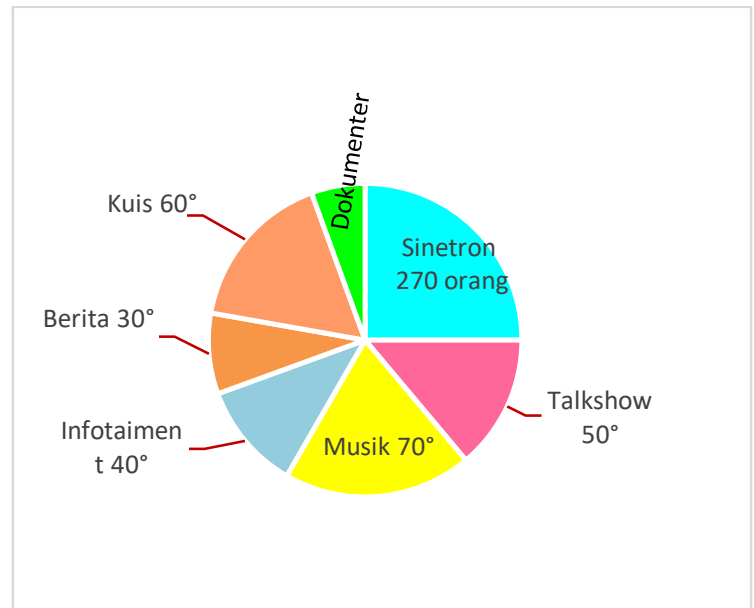

Bagaimana cara agar kita mengetahui banyaknya penggemar film dokumenter?

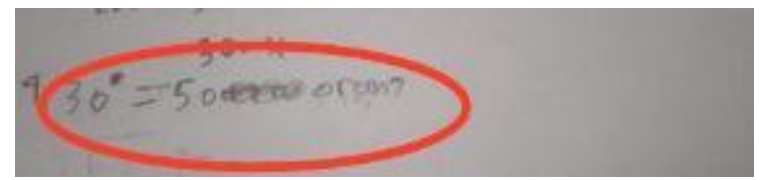

Gambar 7Jawaban siswa Asoal4

Soal tersebut untuk mengatahui berapa jumlah penggemar film dokumenter dari diagram lingkaran dengan perhitungan derajat. Siswa menjawab $30^{\circ}$ seharusnya $20^{\circ}$. Karena dari soal diketahui penggemar sinetron $90^{\circ}$, talkshow $50^{\circ}$, musk $70^{\circ}$, infotaiment $40^{\circ}$, berita $30^{\circ}$, kuis $60^{\circ}$. Sehingga satu putaran itu $360^{\circ}$. Maka akan diperoleh $360^{\circ}-90^{\circ}-50^{\circ}-70^{\circ}-40^{\circ}-30^{\circ}-60^{\circ}=$ $20^{\circ}$. Setelah mengetahui berapa derajat tinggal mencari berapa orang keseluruhan penggemar film tersebut, jadi bisa didapat 
hasilnya berjumlah berapa yang menggemari dokumenter. Dari jawaban dapat dilihat siswa tidak menggunakan cara untuk mendapatkan nilai $30^{\circ}$ tersebut, siswa juga kurang memahami soal dalam gambar diagram lingkaran, sehingga jawaban yang diberikannya keliru.

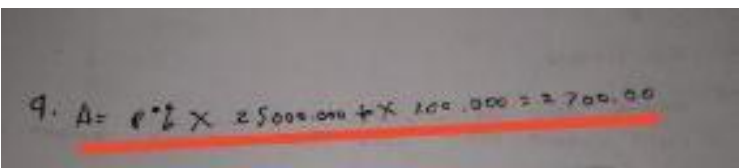

Gambar 8 Jawaban siswa B soal 4

Kurang fokus dalam membaca atau melihat soal yang diberikan, sehingga ketika menjawab soal siswa keliru menjawab. Seharusnya jawaban tersebut untuk soal 5 bukan soal 4 . Soalnya juga dengan diagram lingkaran dengan menggunakan perhitungan derajat bukan persen, dan tidak ada sangkutpaut dengan (\%).

Soal no 5

Perhatikan tabel dibawah ini!

\begin{tabular}{|c|c|}
\hline $\begin{array}{c}\text { Nama } \\
\text { Karyawan }\end{array}$ & Besar Gaji \\
\hline A & 2500000 \\
\hline B & 1800000 \\
\hline C & 2200000 \\
\hline D & 2000000 \\
\hline E & 1700000 \\
\hline F & 1900000 \\
\hline G & 2200000 \\
\hline H & 2250000 \\
\hline
\end{tabular}

Sebagai hasil RUPS pada suatu perusahaan, menetapkan aturan kenaikan gaji sebagai berikut: Gaji yang kurang atau sama dengan Rp. 2.000.000 mendapat 12\% kenaikan gaji, sedangkan gaji lebih dari Rp. 2.000.000 akan mendapatkan kenaikan 8\%. Berapakah gaji rata-rata buruh setelah kenaikan?

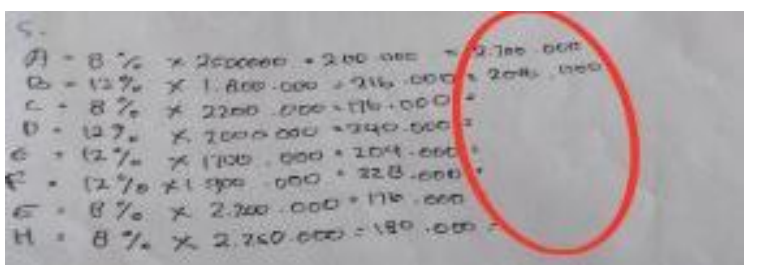

Gambar 9 Jawaban siswa Asoal5
Untuk mengetahui rata-rata gaji buruh setelah mengalami kenaikan, dari jawaban siswa sudah benar dari cara menentukan berapa kenaikan gaji (\%) yang didapat oleh setiap buruh, tetapi siswa kesulitan untuk menentukan jawaban dengan cara menghitung jumlah berapa keuntungan yang didapat setelah mendapat kenaikan gaji (\%), dilihat dari jawaban yang kurang tepat, adapun penyelesaian jawaban siswa belum selesai.

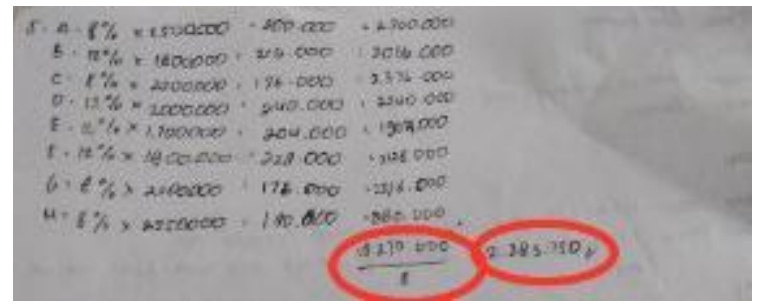

Gambar 10 Jawaban siswa B soal 5

Siswa dalam penyelesaian soal tersebut sudah bagus, jawaban sudah hampir sempurna, sudah menentukan berapa persen keuntungan setiap buruh, sudah mengitung gaji buruh sesudah di berikan keuntungan (\%). Hanya saja penyelesaian akhir siswa kurang ketelitian saja dalam membagi hasil keuntungan dengan jumlah karyawan, siswa memberikan jawaban 2.283.750 seharusnya 2.271.250 hanya selisih 12.500 saja.

\section{Simpulan}

Berdasarkan hasil dari pembahasan dapat disimpulkan keseluruhannya bahwa kesalahan siswa yang dilakukan dalam menyelesaikan masalah soal statitsika kelas VIII diantaranya: siswa kurang pemahaman konsep dari materi statistika, kurangnya ketelitian ketika merampungkan soal perhitungan dan membaca soal, terlalu terburu-buru dalam mengerjakan soal, kesulitan saat merancang strategi model matematika untuk selesaikan soal tersebut sehingga penyelesaiannya tidak lengkap atau kurang tepat, sulit ketika soal dalam diagram, kurang mengerti dalam membaca data dengan diagram.Berdasarkan kesimpulan di atas, penulis menyampaikan sebagian saran untuk mengatasi kesalahan-kesalahan yang sering siswa lakukan pada saat menyelesaikan soal-soal matematika 
khususnya statistika, bahwa dalam belajar, hendaknya siswa memperhatikan apa yang diajarkan oleh gurunya dengan serius supaya yang disampaikan berupa materi bisa dimengerti dan terbayang oleh siswa. Selain itu, siswa harus lebih banyak latihan soal, berhati-hati dan harus teliti ketika membaca soal serta menghitungnya, mengoreksi kembali jawaban sebelum dikumpulkan untuk menghindari jawaban yang salah. Metode yang guru terapkan juga harus inovatif dan kreatif, supaya siswa lebih tertarik pada proses berlangsungnya pembelajaran dan tidak cepat bosan.

\section{Daftar Pustaka}

[1] Agustiva, W. O., Ndia, L., \& Ikman, I. [10] (2016). Analisis Kesalahan Siswa Dalam Menyelesaikan Soal Statistika (Studi Kualitatif Pada Siswa Kelas VII SMP Negeri 4 Kendari). Jurnal Penelitian Pendidikan Matematika, 4(1), 14.

[2] Amin, A. K. (2016). Analisis Bahan Ajar[11] Modul Statistika Pada Program Studi Penddikan Matematika IKIP PGRI Bojonegoro. Jurnal EDUTAMA, 3(2), 8.

[3] Aulia, D., Yarmayani, A., \& Fitriani, S. (2017). Analisis Kesalahan Siswa Dalam[12] Menyelesaikan Soal Matematika Pada Pokok Bahasan Statistika di Kelas XI SMA N 08 Tanjung Jabung Timur Tahun Ajaran 2015/2016. PHI: Jurnal[13] Pendidikan Matematika, 1(1), 10.

[4] Bernard, M. (2015). Membuat Data Kelompok Untuk Pembelajaran Statistik Dengan Berbantuan Microsoft Excel Dengan VBA. Prosiding Seminar Nasional Matematika dan Pendidikan Matematika STKIP Siliwangi Bandung,[14] 3, 8 .

[5] Djafar, S. (2018). Pengaruh Kecemasan Belajar Matematika, Persepsi Siswa Tentang Keterampilan Mengajar Guru, dan Iklim Kelas Terhadap Hasil Belajar Matematika Melalui Motivasi Belajar[15] Pada Siswa Kelas VIII SMP Negeri di Tana Toraja. EDUMASPUL Jurnal Pendidikan, 2(1), 13.

[6] Garfield, J., Le, L., Zieffler, A., \& BenZvi, D. (2014). Developing students' reasoning about samples and sampling variability as a path to expert statistical thinking. Educ Stud Math, 16.

[7] Hafiyusholeh, M. (2015). Literasi Statistik dan Urgensinya Bagi Siswa. WAHANA, 64(1), 8.

[8] Inayah, N. (2016). Pengaruh Kemampuan Penalaran Matematis dan Gaya Kognitif Terhadap Kemampuan Komunikasi dan Koneksi Pada Materi Statistika Siswa SMA. Journal of EST, 2(2), 7.

[9] Indahsari, A. T., \& Fitriana, A. Y. (2019). Analisis Kemampuan Pemecahan Masalah Siswa Kelas X Dalam Menyelesaikan SPLDV. Jurnal Pembelajaran Matematika Inovatif, 2(2). Irmawati, M., Rukli, R., \& Baharullah, B. (2019). Pengembangan Perangkat Pembelajaran Matematika Menggunakan Metode Discovery Learning Berbasis GRANDER di Sekolah Dasar. Edumaspul: Jurnal Pendidikan, 3(2).

Maryati, I., \& Priatna, N. (2017). Anaisis Kesulitan Dalam Materi Statistika Ditinjau Dari Kemampuan Penalaran dan Komunikasi Statistika. Jurnal PRISMA Universitas Suryakancana, VI(2), 7.

Permendikbud. (2016). Peraturan Menteri Pendidikan dan kebudayaan tentang Kompetensi Inti dan Kompetensi Dasar. Jakarta.

Rohaeti, E. E., \& Hendriana, H. (2016). Penguasaan Guru Matematika Sekolah Menengah Terhadap Pembelajaran Inovatif Berbasis Penelitian Melalui Kegiatan Lesson Study. Edusentris, Jurnal Ilmu Pendidikan dan Pengajaran, 3(3), 7.

Sariningsih, R. (2014). Pendekatan Kontekstual Untuk Meningkatkan Kemampuan Pemahaman Matematis Siswa SMP. Jurnal Ilmiah Program Studi Matematika STKIP Siliwangi Bandung, 3(2), 14.

Takaria, J. (2015). Peningkatan Literasi Statistis, Representasi Matematis, dan Self Concept Mahasiswa Calon Guru Sekolah Dasar Melalui Model Collaborative Problem Solving. Disertasi Pasca Sarjana UPI Bandung, 16. 
[16] Tishkovskaya, S., \& Lancaster, G. A. (2012). Statistical Education in the 21st Century: A Review of Challenges, Teaching Innovations and Strategies for Reform. Journal Of Statistics Education, 20(2), 56.

[17] Yusuf, Y., R, N. T., \& W, T. Y. (2017). Analisis Hambatan Belajar (Learning Obstacle) Siswa SMP Pada Materi Statistika. AKSIOMA, 8(1), 11.

[18] Zanthy, L. S. (2016). Pengaruh Motivasi Belajar Ditinjau Dari Latar Belakang Pilihan Jurusan Terhadap Kemampuan
Berpikir Kritis Mahasiswa di STKIP Siliwangi Bandung. Jurnal Teori dan Riset matematika (TEOREMA), 1(1), 7.

\section{Profil Penulis}

Nama Bila Aprilia. Lahir di Bandung pada tanggal 24 April 1998. Sekarang sedang menempuh jenjang pendidikan sarjana S1 dan mengambil program studi pendidikan matematika di IKIP Siliwangi, Cimahi. 